\title{
Electrophoretic Study of Cerebrospinal Fluid Protein Components
}

\author{
Part 1. Survey in Normal Liquor \\ By \\ Zenryu Tanaka \\ (田 中 善 立) \\ From the Department of Neuropsychiatry, Tohoku University, \\ Sendai; Director: Prof. T. Ishibashi \\ (Received for publication, March 11, 1955)
}

The measurement of total protein content and the proportion of globulin in the cerebrospinal fluid (liquor) have long been used as a practical aid method for clinical diagnosis of various neurological diseases, especially in neurosyphilis. Recently the study by means of the electrophoretic method has been established, nevertheless, there are few data obtained from the liquor by this method. This might in part be due to the fact that the protein amount contained in the liquor is too small to make chemical analysis in detail.

By means of the Tiselius' electrophoresis, ${ }^{11}$ the author has studied this problem for the past three years and recently has been able to reach the conclusion that the electrophoretic pattern of the concentrated liquor was almost similar to that of the serum. In this paper, the results from the cases in which each liquor was diagnosed by the routine clinical diagnostic method $^{2 / 3)}$ are reported briefly.

\section{EXPERIMENTAL}

Methods and Subjects

During the procedure of pneumoencephalography, the liquor was obtained from each patient as large as $80 \mathrm{ml}$. This liquor, part of which was examined by routine clinical methods, was then dialysed, putting into a dialysing cellophane sac for about 24 hours against running water. Following this procedure, the liquor was immediately concentrated under diminished pressure to the extent of $10-15 \mathrm{~mm} . \mathrm{Hg}$ at $20^{\circ} \mathrm{C}$. This materials, then, was redialysed against a phosphate buffer at $\mathrm{pH} 7.8$ and ionic strength of 0.145 . The protein concentrations of these samples estimated by refractometer varied from $0.8 \%$ to $1.2 \%$ and the concentrated liquor was finally analysed by the Tiselius apparatus made by Hitachi Co. 
In each case, the areas under enlarged curves of the descending boundaries taken from different angles were measured by a planimeter and the concentration of the liquor components on the average value was calculated in term of per cent against the total protein amount.

It is difficult to obtain a large dosis of liquor from the normal subjects, therefore, the author selected the liquor obtained from a series of the socalled "functional psychosis" having the following characters : no history of syphilis and alcohol-addiction, negative Wassermann' reaction of the liquor and the serum, negative Pandy and Nonne's reactions, normal colloidal reaction and especially normal pneumoencephologram. ${ }^{56)}$ And, at the time of liquor puncture, these patients had of course been in normal condition in both somatic and psychotic spheres after clinical treatment.

\section{Results}

As shown in Table I, the total protein amount was estimated as high as $100 \mathrm{ml}$ in mean value, ranging from 14 to $28 \mathrm{mgm}$. The mobility of each fraction and the concentration of protein components are shown in Fig. 1 and Table II. Concerning the mobility of the liquor, it might be able to say that the results correspond closely to the condition recognizable in the blood. Also, some cases showed to contain a small amount of the component designated as " $\mathrm{X}$ " which had such a mobility being faster than that of albumin, as shown in Fig. 1 (A, B, and D). Among those 19 cases studied, a clearly resolved component of anodic mobility being greater than albumin was recognized in 4 cases. The mean value of the $\mathrm{X}$-component was $0.4 \mathrm{mgm}$. per $100 \mathrm{ml}$.

The percentage composition and the amount of each fraction in $\mathrm{mg}$. $100 \mathrm{ml}$. are also shown in Table II. The albumin/globulin ratio in normal liquor was 1.2 in mean value. The relation between the normal globulin/ albumin quotient and its related values are shown in Table III. In those cases, the mean value of globulin/albumin quotient was calculated at 0.83 .

\section{Comment}

Kabat et al., using a phosphate-sodium chloride buffer mixture at $\mathrm{pH} 7.4$ and ionic strength of 0.2 , reported the existence of the so-called fast component in $3 \%$ among 40 cases. Concerning the liquor obtained from 22 cases, though insufficiently concentrated, Scheids ${ }^{9)}$ observed this fast component only in one case. Also, Fisk et al., ${ }^{10)}$ using a Klett Tiselius apparatus, reported almost same findings. Recently, Pieper, ${ }^{11)}$ using the paper strip electrophoresis, recognized a rapidly migrating component in the normal liquor. Also as described above, we found a rapidly migrating component in the electrophoretic patterns of concentrated liquor equili- 
TABLE I

Total Protein in mg. per $100 \mathrm{ml}$.

\begin{tabular}{r|c|l|c|c}
\hline $\begin{array}{c}\text { Case } \\
\text { No. }\end{array}$ & Age & Clinical Diagnosis & $\begin{array}{c}\text { Total Protein } \\
\text { mg\% }\end{array}$ & Cell Count \\
\hline 1 & 50 & Neurosis & 27 & $2 / 3$ \\
2 & 24 & Anxiety State & 21 & $1 / 3$ \\
3 & 43 & Neurosis & 25 & $1 / 3$ \\
4 & 43 & Neurosis & 23 & $2 / 3$ \\
5 & 30 & Neurosis & 24 & $1 / 3$ \\
6 & 34 & Neurosis & 28 & $6 / 3$ \\
7 & 32 & Anxiety State & 22 & $5 / 3$ \\
8 & 19 & Philoponism* & 14 & $2 / 3$ \\
9 & 16 & Philoponism & 18 & $1 / 3$ \\
10 & 43 & Philoponism & 26 & $5 / 3$ \\
11 & 26 & Philoponism & 24 & $0 / 3$ \\
12 & 21 & Philoponism & 18 & $4 / 3$ \\
13 & 19 & Philoponism & 18 & $1 / 3$ \\
14 & 24 & Neurosis & 20 & $2 / 3$ \\
15 & 18 & Philoponism & 21 & $1 / 3$ \\
16 & 38 & Neurosis & 20 & $1 / 3$ \\
17 & 27 & Neurosis & 20 & $4 / 3$ \\
18 & 23 & Philoponism & 23 & $3 / 3$ \\
19 & 23 & Philoponism & 20 & $2 / 3$ \\
& $*$ Philoponism means psychosis due to wake-amine-intoxication.
\end{tabular}

brated with a phosphate buffer, though the value of components was comprised about $1.5 \%$ in the total protein.

Bücher et al., ${ }^{12)}$ stated that the tau-fraction which possessed its position between beta-globulin and gamma-globulin, might be a specific fraction observable in the normal liquor. The existence of this tau-fraction was ascertained by Mies, ${ }^{13)}$ Gries et al. ${ }^{1415)}$ Plückthum et al. ${ }^{16)}$ stated that this fraction was composed of beta-2- globulin, considering it as the same fraction of that found in the serum. Ewerbeck ${ }^{17)}$ describes this fraction as phi-fraction which shows a mobility resembling to that of gamma-globulin. However, we have thought this phi-fraction would be the gamma-1-fraction, because the mobility of gamma-1-fraction, obtained by the author, was almost similar to that of the phi-fraction, as shown in Fig. 1-C. Esser ${ }^{18)}$ states that the beta-globulin contained in the liquor has such a significant meaning as the so-called "Cerebrogener Anteil" which is specific to the liquor itself. However, we do not like to agree with his opinion, because, in our results, the beta-globulin was almost same as that of the serum in both quantity and quality, and, therefore, the beta-globulin would not be 


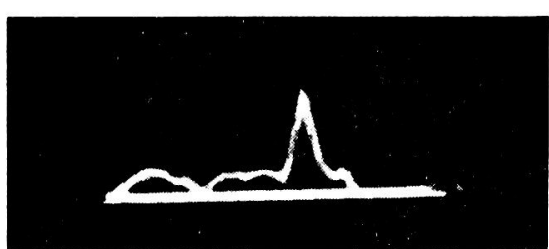

A. Normal

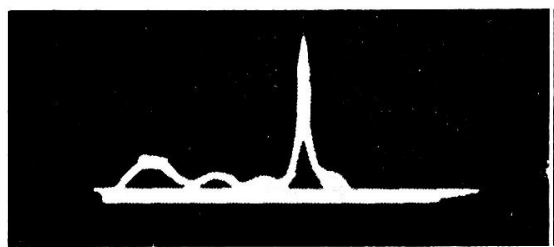

B. Schizophrenia

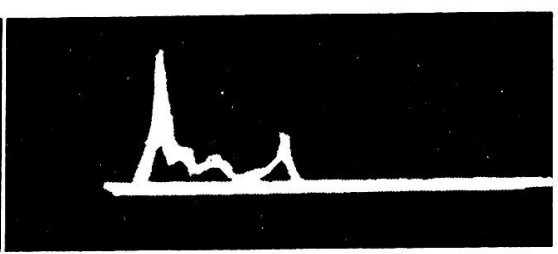

C. General Paralysis



D. Epilepsy

Fig. 1. Electrophoretic patterns of the spinal fluid in phosphate buffer $\mathrm{pH} 7.8$ and 1.0.145. Temperature of test, $20^{\circ} \mathrm{C}$. Exposure after starting current, 52 minutes. Mobilities of the components in liquid A :

$$
\begin{aligned}
& \mathrm{X}: \frac{1.7 \times\left(\frac{64 \times 0.0082}{125}\right) \times 0.3}{3120 \times 0.08}=8.58 \mathrm{~cm}^{2} \cdot \mathrm{volt}^{-1} \cdot \mathrm{sec}^{-1} \cdot 10^{-6} \\
& \text { Alb. }: \frac{1.5 \times\left(\frac{64 \times 0.0082}{125}\right)}{3120 \times 0.08}=0.3 .57 \mathrm{~cm}^{2} \cdot \mathrm{volt}^{-1} \cdot \mathrm{sec}^{-1} \cdot 10^{-6}
\end{aligned}
$$

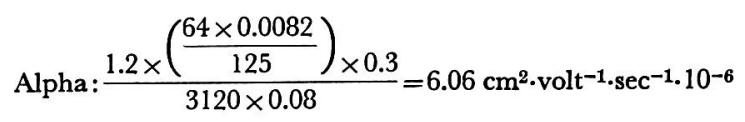

$$
\begin{aligned}
& \text { Beta }: \frac{0.8 \times\left(\frac{64 \times 0.0082}{125}\right) \times 0.3}{3120 \times 0.08}=4.04 \mathrm{~cm}^{2} \cdot \mathrm{volt}^{-1} \cdot \mathrm{sec}^{-1} \cdot 10^{-6} \\
& \text { Gamma : } \frac{0.1 \times\left(\frac{64 \times 0.0082}{125}\right) \times 0.3}{3120 \times 0.08}=0.51 \mathrm{~cm}^{2} \cdot \mathrm{volt}^{-1} \cdot \mathrm{sec}^{-1} \cdot 10^{-6}
\end{aligned}
$$

specific to the liquor.

In addition, concerning the mean value of gamma-globulin, it is interesting to compare our data with the European authors' because the value in our date were slightly higher than theirs.

\section{Summary}

Electrophoretic study of the protein components in the normal cerebrospinal fluid was reported. In 4 of 19 cases, a rapidly migrating component was observed. The fast components were comprised to about $1.5 \%$ in the total spinal fluid proteins. The percentage composition of the spinal fluid protein was as follows: $\mathrm{X}, 1.5$; albumin, 52.8 ; alpha-albumin, 7.3 ; 
TABLE II

Concentration of the Protein Components of Normal Cerebrospinal Fluid

Where two values are given, the values refer to the composition of alpha-1 and alpha- 2 or beta- and beta- 2 components.

\begin{tabular}{|c|c|c|c|c|c|c|c|c|c|c|}
\hline \multirow{3}{*}{$\begin{array}{l}\text { Case } \\
\text { No. }\end{array}$} & \multicolumn{5}{|c|}{ Per cent composition } & \multicolumn{5}{|c|}{ Mgm./100 ml. (calculated) } \\
\hline & \multirow{2}{*}{$\mathbf{x}$} & \multirow{2}{*}{$\mathbf{A}$} & \multicolumn{3}{|c|}{ Globulin } & \multirow{2}{*}{$\mathrm{x}$} & \multirow{2}{*}{ A } & \multicolumn{3}{|c|}{ Globulin } \\
\hline & & & $\alpha$ & $\beta$ & $r$ & & & $\alpha$ & $\beta$ & $\gamma$ \\
\hline 1 & 1.4 & 47.0 & 8.5 & 17.6 & 25.5 & 0.4 & 12.7 & 2.3 & 4.8 & 6.8 \\
\hline 2 & & 54.0 & 7.1 & 14.5 & 24.4 & & 11.3 & 1.5 & 3.0 & 5.1 \\
\hline 3 & & 49.0 & 8.6 & 17.4 & 25.0 & & 12.3 & 2.2 & 4.3 & 6.2 \\
\hline 4 & & 56.0 & 7.9 & 17.9 & 18.2 & & 12.9 & 1.8 & 4.1 & 4.2 \\
\hline 5 & & 48.0 & 9.4 & 17.8 & 24.8 & & 11.5 & 2.3 & 4.2 & 5.9 \\
\hline 6 & 2.7 & 46.2 & 9.2 & 18.0 & 23.8 & 0.8 & 12.9 & 2.6 & 5.0 & 6.7 \\
\hline 7 & & 53.0 & 7.3 & 15.4 & 24.3 & & 11.7 & 1.6 & 3.4 & 5.3 \\
\hline 8 & & 56.0 & 5.0 & 18.0 & 21.0 & & 7.8 & 0.7 & 2.5 & 3.0 \\
\hline 9 & & 53.0 & 5.6 & 17.3 & 24.1 & & 9.5 & 1.0 & 3.1 & 4.4 \\
\hline 10 & & 55.0 & 9.4 & 10.8 & 24.7 & & 14.3 & 2.4 & 2.8 & 6.4 \\
\hline 11 & & 57.0 & 9.8 & 15.1 & 18.1 & & 13.7 & 2.3 & 3.6 & 4.4 \\
\hline 12 & 1.2 & 48.0 & 8.5 & 17.3 & 25.1 & 0.2 & 8.6 & 1.5 & 3.2 & 4.5 \\
\hline 13 & & 56.0 & 8.7 & 10.0 & 25.3 & & 10.1 & 1.6 & 1.8 & 4.5 \\
\hline 14 & & 55.0 & 6.0 & 14.2 & 24.7 & & 11.0 & 1.2 & 2.8 & 4.9 \\
\hline 15 & & 56.0 & 6.1 & 16.0 & 21.9 & & 11.8 & 1.3 & 3.3 & 4.6 \\
\hline 16 & & 49.0 & 8.6 & 17.8 & 24.6 & & 9.8 & 1.7 & 3.6 & 4.9 \\
\hline 17 & 0.8 & 54.0 & 6.4 & 13.6 & 25.2 & 0.2 & 10.8 & 1.3 & 2.7 & 5.0 \\
\hline 18 & & 56.5 & 3.2 & 17.7 & 22.6 & & 13.0 & 0.7 & 4.1 & 5.2 \\
\hline 19 & & 55.4 & 3.7 & 15.5 & 25.4 & & 11.1 & 0.7 & 3.1 & 5.1 \\
\hline Mean & 1. & 52.8 & 7.3 & 15.8 & 23.6 & 0.4 & 11.4 & 1.6 & 3.4 & 5.1 \\
\hline
\end{tabular}

beta-globulin, 15.9; and gamma-globulin, 23.6. The albumin/globulin quotient in the normal cerebrospinal fluid was 1.2 in meaned value.

For the technical assistance, the author wishes to express his gratitude to Messrs. Maki and Hakomori of the Medico-chemical Institute, Tohoku University.

\section{References}

1) Tiselius, Biochem. J., 1937, 31, 1469.

2) Kafka, Nervenarzt., 1951, 9, 341.

3) Demme, Die Liquordiagnostik in Klinik und Praxis., Urban and Schwarzenberg, München-Berlin, 1950.

4) Demme, Fortschr. Neurol., 1953, 21, 472. 


\section{TABLE III}

Relation between Albumin and Globulin in the Normal Cerebrospinal Fluid

\begin{tabular}{r|c|c|c|c|c}
\hline $\begin{array}{c}\text { Case } \\
\text { No. }\end{array}$ & $\begin{array}{c}\text { Globulin } \\
\text { Albumin }\end{array}$ & $\begin{array}{c}\text { Alpha-Glob. } \\
\text { Albumin } \%\end{array}$ & $\begin{array}{c}\text { Beta-Glob. } \\
\text { Albumin } \%\end{array}$ & $\begin{array}{c}\text { Gamma-Glob. } \\
\text { Albumin } \%\end{array}$ & $\begin{array}{c}\text { Albumin } \\
\text { Globulin }\end{array}$ \\
\cline { 2 - 3 } 2 & 1.09 & 17.5 & 36.3 & 52.6 & 0.91 \\
3 & 0.85 & 13.1 & 26.8 & 45.1 & 1.17 \\
4 & 1.01 & 17.5 & 35.5 & 51.0 & 0.99 \\
5 & 0.78 & 14.1 & 31.1 & 32.5 & 1.27 \\
6 & 1.07 & 19.5 & 37.0 & 51.6 & 0.92 \\
7 & 1.10 & 13.7 & 29.0 & 45.8 & 0.90 \\
8 & 0.88 & 18.8 & 36.7 & 47.2 & 1.13 \\
9 & 0.79 & 8.9 & 33.4 & 37.4 & 1.25 \\
10 & 0.89 & 10.5 & 32.6 & 45.5 & 1.11 \\
11 & 0.81 & 17.0 & 19.6 & 44.9 & 1.23 \\
12 & 0.75 & 17.1 & 26.4 & 31.8 & 1.33 \\
13 & 1.06 & 17.0 & 37.2 & 51.0 & 0.93 \\
14 & 0.78 & 15.5 & 17.8 & 45.1 & 1.27 \\
15 & 0.80 & 10.9 & 25.8 & 44.9 & 1.23 \\
16 & 0.77 & 10.9 & 28.5 & 39.1 & 1.28 \\
17 & 1.04 & 17.0 & 36.3 & 50.2 & 0.96 \\
18 & 0.83 & 11.7 & 24.8 & 45.9 & 1.20 \\
19 & 0.76 & 5.6 & 31.3 & 40.0 & 1.30 \\
\hline Mean & 0.80 & 6.6 & 27.9 & 45.8 & 1.24 \\
\hline & 0.83 & 13.8 & 30.2 & 45.5 & 1.20
\end{tabular}

5) Davidoff \& Dyke, Normal Encephalogram., Lea \& Febiger, Philadelphia, 1937.

6) Davidoff \& Epstein, The Abnormal Pneumoencephalogram., Lea \& Febiger, Philadelphia, 1950.

7) Kabat, J. Clin. Invest., 1942, 21, 571.

8) Kabat, Landow \& Moor, Proc. Soc. Exper. Biol. \& Med., 1942, 49, 260.

9) Scheid \& Scheid, Arch. f. Psychiatr., 1944, 117, 641.

10) Fisk, Chanutin \& Klingman, Proc. Soc. Exper. Biol. \& Med., 1951, 78, 1.

11) Pieper, Klin. Wschr., 1954, 32, 597.

12) Bücher, Matzelt \& Pette, ibid., 1952, 30, 325.

13) Mies, ibid., 1953, 31, 159.

14) Gries, Aly \& Oldershausen, ibid., 1953, 31, 644.

15) Hoch \& Chanutin, Proc. Soc. Exper. Biol. \& Med., 1952, 81, 628.

16) Plückthum \& Mattes, Z. Kinderheilk., 1953, 72, 521.

17) Ewerbeck, Klin. Wschr., 1950, 28, 692.

18) Esser \& Heinzler, Dtsch. med. Wschr., 1952, 77, 43. 